\title{
PANORAMA DO SANEAMENTO AMBIENTAL BRASILEIRO: REVISÕES E PERSPECTIVAS
}

Ricardo Siqueira Dias Naves Caldeira ${ }^{1}$

Ricardo Alexandrino Garcia ${ }^{2}$

\section{Resumo}

O saneamento ambiental adequado é um direito básico de todo cidadão, e teoricamente deve ser garantido pelo Estado. No entanto,as políticas públicas nacionais apresentam grande instabilidadedesde meados do século XIX,e por isso ainda buscamalcançara universalidade, equidade e integralidade dos serviços prestados. Refletindo tal situação, o arcabouço acadêmico é recente - decorrente de movimentos socioambientais das décadas de 1960 e 1970 - e o acúmulo de saberes incipiente, o queresulta em baixos investimentos públicos em inovação de tecnologia nesse campo de estudos. Procurou-se nesse trabalho realizado exclusivamente através de revisão bibliográfica, reproduzir e consolidar postulados teóricos que envolvem o saneamento ambiental. Além disso, buscou-se contribuir com esse corpo de verdades, amarrado a conceitos multidisciplinares com enfoqueao desenvolvimento social, que é origem e resultado de uma qualidade ambiental avultada.

Palavras-chave: Saneamento ambiental. Políticas públicas.Desenvolvimento. Diretrizes.

${ }^{1}$ Geógrafo e pesquisador do Leste - IGC/UFMG

2Professor do departamento de geografia do IGC/UFMG 


\section{1- INTRODUÇÃO}

Neste trabalho, serão expostos diversos conceitos acerca da temática do saneamento ambiental; nesta seção, procura-se explicitá-los a fim de exaurir possíveis dúvidas as quais possam surgir. Intenta-se, dessa forma, circunscrever o terreno da pesquisa, demonstrando os alicerces teóricos pertencentes a ela.

É preciso, antes de mais nada, debruçar-se sobre a legislação brasileira no que diz respeito ao saneamento ambiental. A Constituição Federal de 1988 "prevê o direito à salubridade ambiental e a obrigatoriedade dos municípios de cuidarem de serviços essenciais de interesse local” (BRASIL, 2006). As diretrizes nacionais para o saneamento básico são estabelecidas pela lei 11.445/2007; esse ditame norteia os serviços em saneamento do país e é calcado nos princípios de universalização do acesso, integralidade, respeito às peculiaridades e renda da população, articulação com políticas de desenvolvimento locais/regionais, eficiência e sustentabilidade econômica, transparência, controle social, segurança, qualidade e integração à gestão dos recursos hídricos.

Segundo Heller (1998, p. 75), padronizou-se, no Brasil, a demarcação de 5 elementos constituintes do saneamento:

- abastecimento de água, caracterizado como o fornecimento às populações de água em quantidade suficiente e com qualidade que a enquadre nos padrões de potabilidade;

- esgotamento sanitário, compreendendo a coleta dos esgotos gerados pelas populações e sua disposição de forma compatível com a capacidade do meio ambiente em assimilá-los;

- limpeza pública, incluindo todas as fases de manejo dos resíduos sólidos domésticos,até sua disposição final, compatível com as potencialidades ambientais;

- drenagem pluvial, significando a condução das águas pluviais, de forma a minimizar seus efeitos deletérios sazonais sobre as populações e as propriedades;

- controle de vetores de doenças transmissíveis,especialmente artrópodes e roedores.

Os resíduos sólidos são considerados pela Associação Brasileira de Normas Técnicas (ABNT) como "resíduos nos estados sólidos ou semi-sólidos que resultam de atividades da comunidade de origem, industrial, doméstica, hospitalar, comercial, agrícola, de serviços e de varrição" (MASSUKADO, 2004 apud SILVA, 2008). Substituiu-se o uso de "lixo" pelo fato deste trazer consigo pecha de incômodo, sujeira, objetos sem valor (SILVA 2008). 
Mais importante que o conceito puro de desigualdade, entende-se a noção de Desigualdade Ambiental, trazida por Torres (1997 apud Alves, 2007) como:

A exposição diferenciada de indivíduos e grupos sociais a amenidades e riscos ambientais. Ou seja, os indivíduos não são iguais do ponto de vista do acesso a bens e amenidades ambientais (tais como ar puro, áreas verdes e água limpa), assim como em relação à sua exposição a riscos ambientais (enchentes, deslizamentos e poluição). Dessa forma, fatores como localização do domicílio, qualidade da moradia e disponibilidade de meios de transporte podem limitar o acesso a bens ambientais, bem como aumentar a exposição a riscos ambientais.

Incorpora-se à desigualdade ambiental (não excluída a dessemelhança socioeconomica) a conceituação de saúde ambiental trazida por Heller (1998). Consideram-se articulados saúde e meio ambiente, embora outros fatores não diretamente pertencentes a tais esferas sejam contribuintes, de modo a qualificar a primeira por intermédio de melhorias no segundo. Tal amarração é consoante à definição dada pela OMS (apud HELLER, 1998 pgs. 74 e 75) de saneamento: "saneamento constitui o controle de todos os fatores do meio físico do homem, que exercem ou podem exercer efeitos deletérios sobre seu estado de bem estar físico, mental ou social" sendo o bem estar físico, mental e social constituintes da descrição de saúde redigida pelo mesmo órgão ${ }^{3}$. A tal formulação aglutina-se o proposto pela Organização Panamericana da Saúde (2007 apud da Silva, 2012), o qual introduz a questão político-institucional à temática:

saneamento é o conjunto de ações que se executam no âmbito do ecossistema humano para o melhoramento dos serviços de abastecimento de água, coleta de esgoto, o manejo dos resíduos sólidos, a higiene domiciliar e o uso industrial da água, em um contexto político, legal e institucional no qual participam diversos atores do âmbito nacional, regional e local.

A Lei Federal no 11.445/2007 considera o saneamento básico como "um conjunto de serviços, infra-estruturas e instalações operacionais de: abastecimento de água [...], esgotamento sanitário [...], limpeza urbana e manejo de resíduos sólidos [...] e drenagem e manejo das águas pluviais urbanas".

Em relação ao saneamento ambiental, o Glossário de Ecologia (1997 apud da Silva, 2012) o caracteriza como uma "série de medidas destinadas a controlar, reduzir ou eliminar a contaminação do ambiente para garantir melhor qualidade de vida para os seres vivos, e especialmente para o homem". O Ministério da Saúde indica o saneamento ambiental como conjunto de ações e medidas que proporcionem melhorias na salubridade ambiental em determinado espaço geográfico, a fim de beneficiar a população residente (BRASIL, 2004 apud da Silva, 2012). Outra definição delimita a área de atuação de seus serviços:

\footnotetext{
${ }^{3}$ Ibid., 1998. 
O conceito de Saneamento Ambiental possui uma abrangência que historicamente foi construída com o objetivo de alcançar níveis crescentes de salubridade ambiental, compreendendo o abastecimento de água, o esgotamento sanitário, o manejo de resíduos sólidos urbanos, o manejo de águas pluviais urbanas, o controle de vetores, a disciplina de ocupação e uso do solo, a fim de promover a melhoria das condições de vida urbana e rural. Dentro desse conceito mais amplo, um recorte cada vez mais utilizado para uma parte do Saneamento Ambiental é a classificação de Saneamento Básico, que envolve os sistemas e serviços para o abastecimento de água, o esgotamento sanitário, a limpeza pública ou manejo dos resíduos sólidos e o manejo de águas pluviais. (BRASIL, 2006).

Como observado por Rubinger (2008) e reproduzido por da Silva (2012), o foco dos conceitos de saneamento é voltado para a infraestrutura e instalações em detrimento dos usuários. Essa lógica dificulta a aproximação entre população e políticas públicas, especialmente em países em desenvolvimento ou subdesenvolvidos, os quais ainda não alcançaram maturidade ambiental.

A Organização Pan-Americana de Saúde [OPAS] (2004 apud HELLER; NASCIMENTO, 2005, p. 26) estabelece diretrizes para a conjuntura política do setor, com os conceitos de,litteris:

- Universalidade: atendimento universal da população alvo das intervenções.

- Equidade: equivalência na qualidade sanitária dos serviços, independente das condições sócio-econômicas do usuário e da realidade urbanística de onde vive.

- Integralidade: atendimento pelos serviços de saneamento com uma visão integral, que entenda o saneamento como um conjunto de ações, envolvendo, pelo menos, o abastecimento de água, o esgotamento sanitário, a limpeza pública, a drenagem pluvial e o controle de vetores.

- Titularidade municipal: reconhecimento e respeito à autonomia municipal, em coerência com o preceito constitucional.

- Gestão pública: a compreensão de que os serviços de saneamento são, por definição, públicos, prestados sob regime de monopólio, essenciais e vitais para o funcionamento das cidades, para a determinação das condições de vida da população urbana e rural, para a preservação do meio ambiente e para o desenvolvimento da economia.

- Participação e controle social: como requisito indispensável para tornar visível e legitimada a diversidade de interesses, bem como para a apropriação dos equipamentos de saneamento pela população.

- Intersetorialidade: integração com o desenvolvimento urbano, a saúde pública e com as áreas ambiental e de recursos hídricos, entendida como indispensável para se atingir o pleno êxito das ações, por natureza complexas. 
- Qualidade dos serviços: incluindo a regularidade, a continuidade, a eficiência, a segurança, a atualidade, a cortesia e a modicidade dos custos.

- Acesso: compatibilização da política tarifária com o poder aquisitivo do usuário, mediante a prática da modicidade dos preços.

A gestão eficaz em saneamento deve trazer consigo tais diretrizes, a fim de atingir não só a excelência na prestação de serviços, como, principalmente, a plena cobertura à população de condições ambientais adequadas. É na esfera da participação popular nas fases de provisão, fiscalização e prestação de contas que o controle social está calcado - além do diálogo SociedadeGoverno na implantação de programas e políticas - sendo os agentes usuários ou não (HELLER; REZENDE; HELLER, 2007).

É possível contextualizar os pensamentos de Bentham (1789) à realidade do saneamento ambiental contemporâneo; lança mão do utilitarismo, o qual tem como princípio o bem-estar (greatesthappiness) da maior quantidade possível de indivíduos, para que seja o único resultado desejável das ações humanas ${ }^{4}$. O filósofo indicava a necessidade dos governos em abordar a população como o fim de suas intervenções, gerando, de certa forma, desenvolvimento. Não obstante, além do aumento direto da felicidade, Bentham também argumentou a favor da necessidade da prevenção de qualquer tipo de perturbação da satisfação da comunidade. Ao observar que a qualidade do governo pode ser mensurada pelo bem-estar comunitário, que nada mais é do que a soma de alegrias individuais ${ }^{5}$, o autor deflagra noções que permeiam a governança em tempos pós-modernos, não excluído o saneamento ambiental. Países considerados desenvolvidos têm conceitos similares ao utilitarismo arraigados em sua concepção de progresso, os quais têm uma construção do saber há muito consolidada.

Seria incongruente pensar em saneamento ambiental sem conectá-lo ao conceito de políticas públicas; estas, segundo Howlett e Ramesh, (2003); Jenkins, (1993); Nelson, (1996) (apud HELLER, 2007, p. 286) são "um processo, que envolve decisões por parte de corpos e autoridades governamentais, e ações, realizadas por um ator ou um conjunto de atores, e é composto por metas e os meios para alcançá-las.” Em temática similar, Marshall (1992, apud HELLER 2007, p. 289) indica que “cidadania seria o 'pertencimento pleno a uma comunidade', ou o conjunto de direitos e obrigações que determinam o caráter das relações entre os indivíduos de uma determinada comunidade política”; não obstante indica que a saúde pública, educação básica e acesso a serviços são constituintes dos direitos sociais e fundamentais de cidadania.

${ }^{4}$ BENTHAM, J. An introduction to the principles of morals and legislation, Chapter 1: of the principle of utility. 1789.

${ }^{5}$ Ibid., pgs. 18 e 19 
O conceito de região não é institucionalizado, havendo inúmeras formulações em diferentes campos cognitivos, sendo impossibilitada a confluência teórica; entretanto, alguns autores caminham em sendas pertinentes ao seguinte trabalho. Para Geiger (2001), a região é construída de maneira organizacional em consonância com ensejos sociais intra e inter espaciais; sobre isso, o autor considera a região um ambiente sistemático entre práticas políticas, produtivas, acadêmicas e sociais, caracterizando uma comunidade de alto grau de entrelaçamento entre seus entes e instituições constituintes. Nesta seara, Cunha, Simões e de Paula (2005) afastam o atrelamento de uma região a uma simples questão paisagística; para os autores este recorte é espaço natural, político, cultural, tecnológico e geohistórico, sujeito a intra e interrelações de seus constituintes. Segundo os autores, a regionalização nada mais seria que a ação analítica específica da região, partindo do território e visando "a compreensão sistematizada do espaço de uma perspectiva histórica" (CUNHA;SIMÕES; de PAULA, 2005, p. 6) utilizando-se de dados coevos e objetivos que expressem a realidade de maneira satisfatória.

Os serviços sanitários no país são prestados de diferentes maneiras, sendo cada uma mais ou menos eficiente e abrangente, existindo correlação com os modelos de prestação (não excluída as características regionais e sociais das localidades): Administração Direta Municipal, as Autarquias Municipais, as Companhias Municipais, as Companhias Estaduais, as Empresas Privadas e os Consórcios Municipais (HELLER, 2012). A seguir, detalham-se os supracitados modelos:

- Administração Direta Municipal: Segundo Heller (2012) os serviços nessa modalidade são executados de forma direta pela administração municipal (prefeituras) através de “secretarias, departamentos e repartições” (p. 15). Tal modelo de gestão apresenta déficit no que tange à accountability, ou seja, à "prestação de contas à comunidade" (HELLER, 2007); a sustentabilidade financeira do saneamento é muitas vezes obnubilada, bem como os subsídios orçamentários e o repasse da receita dos serviços ao caixa municipal (PEIXOTO, 1994 apud HELLER, 2012). Não é incomum, sobretudo em localidades de menor contingente populacional, a existência de funcionários que acumulem funções, o que evidencia a incapacidade de determinados municípios em gerir os serviços em saneamento. Sobre isso, Coutinho (2001, p. 28 apud HELLER, 2012, p. 16) informa que: “Tão folclórico quanto comum é se encontrar, como responsável pela prestação dos serviços, um tal "Zé da Água”, misto de encanador, desentupidor de esgoto, leiturista de hidrômetro, entregador de conta de água, etc”. 
- Autarquias Municipais: Caracterizadas como pertencentes à administração direta, as autarquias são órgãos descentralizados do Poder Público, usualmente nominados SAAE (Serviço Autônomo de Água e Esgoto), SAE (Superintendência de Água e Esgoto) ou DMAE (Departamento Municipal de Água e Esgoto) (HELLER, 2012). Têm autonomia financeira, administrativa e jurídica, são estabelecidas por meio de ato administrativo e garantem o poder decisório à comunidade (FUNASA, 2003 apud HELLER, 2012).

- Companhias Municipais: Marcadas principalmente por seu modelo empresarial de gestão e operação, são atualmente adotadas pela minoria dos municípios brasileiros (HELLER, 2012). Embora existam os encargos sociais e tributários, tal modelo se destaca pela excelente gestão e administração dos recursos, corroborando sua viabilidade no aspecto financeiro (PEIXOTO, 1994 apud HELLER, 2012).

- Companhias Estaduais: Também conhecidas como CESBs, as Companhias são calcadas naautossustentação tarifária e nos subsídios cruzados (tarifas únicas na escala estadual, possibilitando que os serviços superavitários cubram os deficitários por meio de transferência de recursos), a fim de alcançar autonomia financeira (BETTINE, 2003; REZENDE; HELLER, 2008 apud HELLER, 2012). De acordo com o mesmo autor:

As companhias estaduais destacam-se como um modelo de gestão empresarial para a prestação dos serviços de água e esgotos, sob um âmbito regional. As CESBs são empresas de economia mista que obedecem a um sistema centralizador administrativo e financeiro, sendo a operação dos serviços e a manutenção, comumente realizada por meio de escritórios regionais em municípios sedes. (2012, p. 17)

- Empresas privadas: Pouco menos que 5\% de todo serviço em saneamento do Brasil é representado por essa modalidade - números explicados, em parte, pelos grandes investimentos iniciais com retorno em longo prazo necessários. Todavia, desde 2004 (sanção da lei 11.079) o setor recebe incentivos na instalação das Parcerias PúblicoPrivadas (PPPs), gerando prognóstico de melhoria na quantidade e qualidade dos serviços desse modelo de prestação (HELLER, 2012).

- Consórcios Municipais: Modelo de auto-organização intermunicipal (gestão associada) na prestação de serviços em saneamento, marcado por pouca influência Federal e Estadual. (HELLER, 2012).

\section{2- HISTÓRICO DO SANEAMENTO BRASILEIRO}

Em todo estudo realizado, é impossível sua confecção sem revisão histórica; no universo do saneamento ambiental, de certo, não é diferente. O Brasil demonstra grandes avanços em 165 
anos nessa esfera, embora ainda sejam herdadas práticas e políticas vigentes em meados do século XIX. Nesta seção, será apresentada a história do saneamento do país.

Entre as décadas de 1890 e 1940, saneamento e saúde pública urbana e rural estavam relacionados sob a mesma política nacional, quando foram desprendidos ao final desse período (REZENDE; RIBEIRO, 2004). Todavia tal ruptura não era global, havendo experiências de integração ainda vigentes. Ao observar com maior detalhamento, nota-se que durante o século XIX o saneamento era exercido por empresas de capital inglês em poucos municípios de maior eminência político-econômica, enquanto nos decênios subsequentes vigorou a política higienista nas grandes cidades, embora já haviam sido instauradas políticas anti-seca e estudos sobre a defasagem rural em saneamento (BRASIL, 2006).

Sidney Chalhoub em sua obra "Cidade Febril: cortiços e epidemias na Corte imperial" (São Paulo: Companhia das Letras, 1996), ilumina a situação da política higienistavigente entre a segunda metade do século XIX até o início do século XX, especialmente na então capital do império, Rio de Janeiro. Segundo o autor, em meados de 1850 a administração pública começa a correlacionar a existência dos chamados cortiços a epidemias de doenças como febre amarela e cólera, levando as autoridades a olhar com mais atenção a questão do saneamento. Apesar de duas tentativas $(1853,1855)$ de adequar sanitariamente tais moradias via legislação específica do Rio de Janeiro, ambas não lograram êxito devido ao não acolhimento da Câmara Municipal carioca, a qual se limitou a proibir a construção de novos cortiços sem licença, preterindo a situação do saneamento das classes de baixa renda que moravam na cidade. É introduzida de maneira inédita, em 1860, a noção de melhoria da qualidade das habitações populares, visando não apenas moradias dignas como também o incremento das instalações sanitárias existentes. $\mathrm{O}$ documento lavrado pela Secretaria de Polícia da Corte ainda propunha incentivos fiscais e adiantamento pecuniário aos construtores, bem como instaurar "coleta regular de lixo, latrinas limpas e em número suficiente, calçamento, janelas amplas" (pgs. 32 e 33); o ofício traz consigo, logo, o atrelamento de dois elementos fulcrais da qualidade ambiental que ainda persistem: Moradia popular e saneamento adequado. Todavia, como das duas tentativas anteriores, a Câmara Municipal não demonstrara boa vontade em implementar tais postulados. Essas políticas foram ignoradas em favor da abordagem higienista, que ganhara força no discurso de médicos e engenheiros pregando o progresso, a civilização, a limpeza e a beleza inspirado pela cientificidade européia dita neutra, atropelando características do espaço brasileiro. Chalhoub indica que "o que se declara,literalmente, é o desejo de fazer a civilização européia nos trópicos; o que se procura, na prática, é fazer política deslegitimando o lugar da política na história” (p. 35). 
Em 1930 a administração direta fora introduzida em alguns estados, embora não lograsse êxito devido à má gestão de recursos e insuficiência técnica, tendo como corolário o surgimento de movimentos pontuais de autonomia do setor na década de 1950, como a criação dos SAAEs Serviços Autônomos de Água e Esgoto ${ }^{6}$.A lógica tecnocrata, a partir daí, tornou-se hegemônica através Juscelino Kubitschek em uma tentativa de realizar um simulacro das experiências soviéticas e norte-americanas (MATOS, 2004), tendo como apogeu o ínterim centralizador do PLANASA (1970-1980), resultando em baixos avanços em esgotamento e tratamento de efluentes, apesar do grande abastecimento de água potável; entretanto, o Plano apresentava, em meados dos anos 1980, enfraquecimento financeiro e ideológico, hauridos investimentos internacionais, corrupção e má gestão de recursos (MATOS, 2004). Tal lógica ratificara o distanciamento entre saúde e saneamento, iniciado nos anos 1940 e rompidos em meados da década de 1960 em favor da grande máquina estatal racionalizada. Apresentou-se como saída as propostas de descentralização e controle social, levadas a cabo posteriormente 7 .

O Brasil presenciou progresso técnico e científico adequado às demandas sanitárias até a supra data, quando saúde e saneamento foram desagregados de maneira definitiva na gestão pública; sobre o período anterior ao explicitado, Heller e Nascimento (2005, p. 25) afirmam que:

Foi certamente no âmbito das instituições responsáveis pela provisão dos serviços que se iniciaram, aindaque não sistematicamente, investigações, testes, desenvolvimentos e avaliações na área, motivados sobretudo pela transferência de técnicas e processos desenvolvidos nos países ricos e sua necessária adaptação à nossa realidade. Nesse particular, destaca-se a atuação da FSESP Fundação Serviços Especiais de Saúde Pública - e do DNERU - Departamento Nacional de Endemias Rurais.

Os anos 1970 na esfera do saneamento ambiental foram marcados pela abordagem centralizada e intervencionista, consubstanciados na figura do PLANASA - Plano Nacional do Saneamento - financiada pelo BNH (Banco Nacional da Habitação), órgão conspícuo de gestão e financiamento urbanos do Estado Militar. A pesquisa e desenvolvimento (P\&D) na área foi fomentada, embora sem o necessário integralismo nacional e concentrados em demandas econômicas (HELLER; NASCIMENTO, 2005). Tal oximoro começa a ser rompido nos anos 1980 quando incentivos à inovaçõs, especialização e projetos nas universidades são lançados, criando terreno favorável à construção de um pensamento em saneamento, ainda que pouco aplicado à sociedade (ibid. 2005). Os mesmos autores citam na supracitada obra a manutenção do fomento nas décadas de 1990 e 2000, além de criação de grupos de excelência e doutorados cursados no exterior e maior quantidade de órgãos financiadores.

\footnotetext{
${ }^{6}$ Ibid.,2006

${ }^{7}$ Rezende; Ribeiro, 2004, p. 10 
Segundo Matos (2004, p. 52) os anos 1980 se caracterizam como "o momento em que a variável ambiental integra-se aos discursos e políticas públicas", além da criação do CONAMA em 1986 e do IBAMA em 1989; na virada da década, o Programa Nacional do Meio Ambiente (PNMA) é lançado. Nesse decênio (1980) observa-se o esforço internacional em ampliar os serviços de abastecimento de água potável e esgotamento sanitário, por intermédio de agencias multilaterais, encontrando na auto-organização populacional uma forma de gestão eficiente em países subdesenvolvidos. Tal condição surge como embrionária ao condicionamento da participação e controle social para a obtenção de verbas internacionais visandoo estabelecimento de políticas em saneamento (HELLER; REZENDE; Heller, 2007).Nessa conjuntura de redemocratização política e modernização da gestão em que o governo aborda o saneamento básico voltado para as classes de baixa renda, resgata essa parcela da população da obscuridade sanitária dos tempos do PLANASA (BRASIL, 2006).

Os anos de 1990 foram caracterizados por marcada instabilidade no que concerne a implantação de novas diretrizes federais. Em 1992 o Congresso aprovou a proposta da Política Nacional de Saneamento e seus instrumentos, enquanto em 1995 o então presidente Fernando Henrique Cardoso vetou integralmente o projeto - o qual fora substituído pelo Projeto de Modernização do Setor de Saneamento, de viés privativista. No ano seguinte aprova-se a PLS 266/96, responsável por barrar uma parcela da atuação privada e intentando a titularidade do serviço aos estados (BRASIL, 2006). Já sobre o ano de 1999, o Guia para Elaboração de Planos Municipais de Saneamento (2006) aponta que fora:

Firmado acordo com o Fundo Monetário Internacional (FMI). O Brasil comprometeu-se a acelerar e ampliar o escopo do programa de privatização e concessão dos serviços de água e esgoto, limitando o acesso dos municípios aos recursos oficiais. Realização da I Conferência Nacional de Saneamento, apontando para a universalização do atendimento com serviço de qualidade prestado por operadores públicos, reconhecendo o caráter essencialmente local dos serviços e, portanto, a titularidade dos municípios, desenvolvendo mecanismos de controle social e de participação popular na definição da prestação dos serviços.

Por fim o século XXI e a passagem de governo - de FHC para Lula - modificaram o papel da União que agora é regulador e financiador do Saneamento Ambiental, levando em consideração a viabilidade de novos projetos(BRASIL, 2006). O atual momentodos serviços de saneamento ambiental no Brasil é notável em aspectos observados por Costa, 2009; Heller, 2009; Mukai, 2007; Pinheiro, 2009; Rezende e Heller, 2008 (apud HELLER, 2012), dentre os quais:

- Diretrizes em saneamento amplas e integrais, envolvidos seus cinco serviços;

- A participação popular; 
- Regulação dos serviços;

- Obrigatoriedade do planejamento de ações;

- Sustentabilidade econômico-financeira

- Criação do Sistema Nacional de Informações em Saneamento Básico

A Lei Federal no 11.445/2007 dispõe de diretrizes em saneamento a serem seguidas; este ditame dispõe ao titular dos serviços (ente federado competente a realizá-los) a formulação de planos de saneamento juntamente com o Sistema Único de Saúde, além de garantir mecanismos de participação social na elaboração, fiscalização e revisão daspolíticas públicas. A lei institui a Política Federal de Saneamento Básico, orientada em onze diretrizes, litteris:

I - prioridade para as ações que promovam a equidade social e territorial no acesso ao saneamento básico;

II - aplicação dos recursos financeiros por ela administrados, de modo a promover o desenvolvimento sustentável, a eficiência e a eficácia;

III - estímulo ao estabelecimento de adequada regulação dos serviços;

IV - utilização de indicadores epidemiológicos e de desenvolvimento social no planejamento, implementação e avaliação das suas ações de saneamento básico;

V - melhoria da qualidade de vida e das condições ambientais e de saúde pública;

VI - colaboração para o desenvolvimento urbano e regional;

VII - garantia de meios adequados para o atendimento da população rural dispersa, inclusive mediante a utilização de soluções compatíveis com suas características econômicas e sociais peculiares;

VIII - fomento ao desenvolvimento científico e tecnológico, à adoção de tecnologias apropriadas e à difusão dos conhecimentos gerados;

IX - adoção de critérios objetivos de elegibilidade e prioridade, levando em consideração fatores como nível de renda e cobertura, grau de urbanização, concentração populacional, disponibilidade hídrica, riscos sanitários, epidemiológicos e ambientais; 
$\mathrm{X}$ - adoção da bacia hidrográfica como unidade de referência para o planejamento de suas ações; e

XI - estímulo à implantação de infraestruturas e serviços comuns a Municípios, mediante mecanismos de cooperação entre entes federados.

Embora seja uma prescrição que pressupõe maior participação popular e mais adequada à realidade nacional, alguns pontos merecem destaque negativo, como o norteamento vago sobre políticas de saneamento em áreas rurais. Também se ressalta a ruptura entre Saneamento Básico e Recursos Hídricos (embora indique a adequação daquela sobre esta): é impossível pensar em abastecimento de água e esgotamento sanitário sem incluir a questão dos recursos hídricos. Ora, se os municípios estão inscritos em bacias, obviamente o input e outputde água e efluentes no sistema, bem como a qualidade, volume e utilização dos cursos d'água devem ser levados em consideração de maneira una.

A Tabela 1 é trazida por Soares, Bernardes e Cordeiro Netto (2002, p. 1715) como umasíntese do histórico do saneamento no Brasil, sendo referenciada em obras de Branco (1991), Cairncross (1989), Costa (1994) e Heller (1997):

Tabela 1 - Evolução histórica dos aspectos de saúde pública e meio ambiente no setor de saneamento no Brasil.

\section{Período}

Meados do século XIXaté início do século XX

Início do século XXaté a década de 30

\section{Principaiscaracterísticas}

-Estruturação das ações de saneamento sob o paradigma do higienismo, isto é, comouma ação de saúde, contribuindo para a redução da morbimortalidade por doençasinfecciosas, parasitárias e até mesmo não infecciosas

- Organização dos sistemas de saneamento como resposta a situações epidêmicas,mesmo antes da identificação dos agentescausadores das doenças

- Intensa agitação política em torno da questão sanitária, com a saúde ocupando lugarcentral na agenda pública: saúde pública em bases científicas modernas a partirdas pesquisas de Oswaldo Cruz.

- Incremento do número de cidades com abastecimento de água e da mudançana orientação do uso da tecnologia em sistemas de esgotos, com a opção pelo sistemaseparador absoluto, em um processo marcado pelo trabalho de Saturnino de Brito,que defendia planos estreitamente relacionados com as exigências sanitárias (visãohigienista). 
Décadas de 30 e 40

Décadas de 50 e 60

Década de 70

Década de 80

Década de 90 atéo início do século XXI
- Elaboração do Código das Águas (1934), que representou o primeiro instrumentode controle do uso de recursos hídricos no Brasil, estabelecendo o abastecimentopúblico como prioritário.

- Coordenação das ações de saneamento (sem prioridade) e assistência médica(predominante) essencialmente pelo setor de saúde.

- Surgimento de iniciativas para estabelecer as primeiras classificações e os primeirosparâmetros físicos, químicos e bacteriológicos definidores da qualidade das águas,por meio de legislações estaduais e em âmbito federal.

- Permanência da dificuldade em relacionar os benefícios do saneamento com a saúde,restando dúvidas inclusive quanto à sua existência efetiva.

- Predomínio da visão de que avanços nas áreas de abastecimento de águae de esgotamento sanitário nos países em desenvolvimento resultariam na reduçãodas taxas de mortalidade, embora ausentes dos programas de atenção primáriaà saúde.

- Consolidação do Plano Nacional de Saneamento (PLANASA), com ênfase noincremento dos índices de atendimento por sistemas de abastecimento de água.

- Inserção da preocupação ambiental na agenda política brasileira, com a consolidaçãodos conceitos de ecologia e meio ambiente e a criação da Secretaria Especial de MeioAmbiente (SEMA) em 1973

- Formulação mais rigorosa dos mecanismos responsáveis pelo comprometimentodas condições de saúde da população, na ausência de condições adequadasde saneamento (água e esgotos).

- Instauração de uma série de instrumentos legais de âmbito nacional definidores depolíticas e ações do governo brasileiro, como a Política Nacional do Meio Ambiente (1981).

- Revisão técnica das legislações pertinentes aos padrões de qualidade das águas

- Ênfase no conceito de desenvolvimento sustentável e de preservação e conservaçãodo meio ambiente e particularmente dos recursos hídricos, refletindo diretamenteno planejamento das ações de saneamento.

- Instituição da Política e do Sistema Nacional de Gerenciamento de Recursos Hídricos

(Lei 9.433/97).

- Incremento da avaliação dos efeitos e conseqüências de atividades de saneamentoque importem impacto ao meio ambiente. 


\section{3- POLÍTICAS PÚBLICAS}

O saneamento ambiental no Brasil reflete o modo de governança histórico-cultural nacional, caracterizado pela centralização, hierarquia, retiliniedade e patriarcalidade, os quais têm caráter resiliente e não saem da pauta do dia de críticos políticos ao Estado. Entretanto, desde a execução do Plano Real, melhorias no que tangem à participação popular e à "tríade" do saneamento ambiental - Integralidade, Equidade e Universalização - desenvolveram-se. Não alheios a tais princípios, são subutilizadas as variáveis quantitativas e trabalhos acadêmicos sobre as condições sanitárias brasileiras (etapa basilar para toda política pública na área), a guisa de sanar mazelas de tal ordem (REZENDE; RIBEIRO, 2004).

A preocupação ambiental no país, bem como o pensamento do espaço, historicamente são relegados pelo Poder Público, refletindo visões de curto e médio prazo cultivadas em órgãos gestores inseridos na lógica acumuladora dos ciclos econômicos (LIMA, 2013). Esses ciclos podem ser relacionados às origens coloniais/Imperiais dos atuais espaços brasileiros, capazes de ordenar, hierarquizar e ditar práticas políticas e econômicas vigentes no cenário atual (MATOS, 2004). O rompimento com tal realidade é complexo, pois está calcado em uma mudança de comportamento coletivo e político, acompanhando consciência das cidades como organismos ecossistêmicos, as quais circunscrevem o Homem social dependente dos recursos naturais para se reproduzir (LEFF, 2001 apud LIMA, 2013). É comum no país a prática de políticas públicas de visão estritamente setorialista, negligenciando as espacialidades do território, as quais traduzem especificidades regionais, tornando ainda mais complexo o pensamento integrado e participativo que dificilmente observa-se no Brasil (MATOS, 2004).

Heller (2007) aponta dois pressupostos para a implementação de políticas públicas:

(i) o da dependência dessas formulações com o contexto sóciopolítico-econômico em questão, implicando que haveria pelo menos formulações mais apropriadas aos países desenvolvidos e outras diferentes aos países em desenvolvimento, [...]; (ii) o de que as políticas públicas devem ser formuladas e avaliadas considerando o saneamento como um direito social da cidadania.

Dessa forma, há de se planejar para e com a população, considerando as demandas prementes de menor complexidade e dispêndios em um primeiro momento, ulteriormente atingindo os problemas arraigados, abarcando a avaliação de serviços e incorporando o conceito de sustentabilidade ${ }^{8}$.

Uma das potenciais soluções de curto prazo encontra-se na abordagem em menor escala. Segundo Cairncross (et. al. 1996, apud SOARES; BERNARDES; CORDEIRO NETTO, 2002 p.

\footnotetext{
${ }^{8}$ Ibid. 2007 
1721) existem dois domínios de transmissão de doenças: público e domiciliar. A abordagem no escopo familiar é condição sinequa non para mitigação de patologias, sendo que "Algumas vezes, os benefícios nem sempre são resultantes diretos de ações de saneamento, mas sim decorrentes da nova relação ambiental e dos hábitos de comportamento e higiene que se estabelecem (Esrey et al., 1991; Gomes, 1995; VanDersliceeBriscoe, 1995)"9. Mecanismo de extrema conspicuidade, a educação ambiental é deficitária no Brasil - precipuamente em localidades de menor renda -, exercendo parcela importante na culpabilidade aplicada à população por displicência ou inconsciência ambiental, as quais também são motivos para possíveis inadequações sanitárias (LIMA, 2013). Contudo, não se exclui a renda como fator limitante da qualidade ambiental na esfera domiciliar, uma vez que instrumentos de adequação sanitária demandam disponibilidade financeira - nem sempre presente - aos chefes familiares. Há se levar em consideração outros fatores responsáveis pela não adesão domiciliar a serviços de abastecimento de água e esgotamento argumentados por Rezende et al (2007). De acordo com os autores o perfil da demanda por serviços em saneamento é amarrada às variáveis demográficas e socioeconômicas: o abastecimento de água está atrelado à qualidade e quantidade do serviço, enquanto o esgotamento sanitário advém das características culturais e financeiras (estas relacionadas ao valor cobrado pelo serviço) da população; pode-se afirmar que "quando o saneamento fica a cargo do indivíduo, sua cultura e escolaridade são preponderantes nas escolhas que envolvem a situação sanitária domiciliar” (Rezende et al 2007, p. 91).

As ações de governo na área se articulam a políticas públicas e sua gestão, o que pode tornar nebulosa a jurisdição em saneamento ambiental, uma vez que União, entes federados e municípios têm diferentes interesses (HELLER, 2007), competências, recursos e eficiência governamental. Lenton, Wright e Lewis (2005, apud HELLER 2007) indicam duas principais barreiras presentes no saneamento institucionalizado: "a ausência de instituições apropriadas em todos os níveis e a disfunção crônica dos arranjos institucionais existentes”. O autor brasileiro, entretanto, destaca que ao último óbice observam-se "capacidade institucional inadequada, incentivos não-apropriados, desconsideração na prestação de contas à comunidade (accountability) e ausência de sistema regulatório adequado".

Não se negligencia a importância da escala regional nas intervenções sanitárias; além de integrar os recursos naturais circunscritos a tal recorte espacial há de se levar em consideração que "O conhecimento da região se articula com o conhecimento da governança e torna possível o estabelecimento de gestões mais sensitivas e geograficamente específicas” (GEIGER, 2001, p.

\footnotetext{
${ }^{9}$ Soares; Bernardes; Cordeiro Netto, 2002, p. 1721 
1746). Ainda sobre a escala regional na perspectiva da gestão em saneamento, Forster (2005, apud HELLER, 2012) aponta cinco aspectos positivos nesse modelo, litteris:

- Aumento da eficiência através de economias de escala;

- Maior acesso aos recursos hídricos e gerenciamento integrado desses recursos;

- Fortalecimento da capacidade profissional devido à maior escala de operação;

- Acesso ao financiamento e/ou a participação do setor privado;

- Divisão de custos entre áreas de serviços de alto e baixo custo.

O saneamento auspicioso deve se ater à avaliação de efeitos hígidos, ecossistêmicos e sociais, observando, respectivamente, os níveis de morbidade de doenças típicas de inadequação ambiental, biodiversidade afetada e exclusão social (OPAS, 2004 apud HELLER; NASCIMENTO, 2005). O Brasil, entretanto, aborda o saneamento como uma política a ser executada de maneira apartada das demais, especialmente da saúde (HELLER, 1998). Defasagens marcam o esgotamento sanitário brasileiro, eminentemente na etapa de tratamento de efluentes, os quais apresentam índices de remoção satisfatórios apenas nas parcelas de Demanda Bioquímica de Oxigênio (DBO), Demanda Química de Oxigênio (DQO) e Sólidos em Suspensão (SS), segundo von Sperling e Chernicharo (2000, apud SOARES; BERNARDES; CORDEIRO NETTO, 2002 p. 1720).

Heller e Castro (2007, p. 285) afirmam que apesar do saneamento ambiental envolver diversas áreas de conhecimento, há insuficiência de formulações conceituais e metodológicas acerca do tema, refletindo fragmentação científica que impede integração cognitiva; assim, são abertos precedentes para a visão empresarial em detrimento do direito social dos cidadãos:

A visão empresarial aplicada aos serviços de saneamento é coerente com as tentativas de substituir o princípio desses serviços como direito social da cidadania, e que portanto devem responder aos interesses e demandas sociais, por princípios mercantis, em que o ator interpelado é o(a) consumidor(a) ou o cliente, e não o(a) cidadão(ã) portador(a) de direitos, ou seja, valorizando a ponta da oferta em detrimento da visão da demanda pelos serviços e subordinando as necessidades sociais aos requerimentos de eficiência empresarial ${ }^{10}$.

A alternativa almejada para o rompimento do paradigma mercantilista do saneamento é a completa implantação da participação e controle social, abrangendo "agentes públicos, sociedade civil organizada e a população em geral” (BRASIL, 2006). Ora, a cidadania de fato só é alcançada para e pelo povo, e esse instrumento permite à sociedade maior autoridade sobre as benfeitorias sanitárias no país. É através dessa perspectivaque, teoricamente, o atendimento às demandas

${ }^{10}$ Ibid. p. 285 
populares e o feedback à população seria alcançado, homologando princípios como a "impessoalidade, a justiça, a honestidade e a responsabilidade na gestão [...] assim como promover a equidade" (HELLER; REZENDE; HELLER, 2007, p. 43). Em outras palavras, as políticas em saneamento ambiental têm como beneficiário principal o povo, então nada mais óbvio e justo que o agente norteador das diretrizes seja a própria sociedade. Ainda nesta senda, entende-se que um governo municipal que apenas informa as benfeitorias realizadas não é capaz de "metamorfosear" o citadino em cidadão, pois esses habitantes só (re)conhecem a cidade se vivenciarem, participarem, debaterem, fiscalizarem tais intervenções: todos são ouvintes e proponentes. (BRASIL, 2006).

A reforma de antigos paradigmas em saneamento - e adequação a novas formulações em gestão ambiental - é proposta em 2006 pelo Governo Federal, no documento "Guia para a Elaboração de Planos Municipais de Saneamento”, que indica os princípios a serem seguidos nos Planos locais, a saber, litteris:

- Integração de diferentes componentes da área de Saneamento Ambiental e outras que se fizerem pertinentes;

- Promoção do protagonismo social a partir da criação de canais de acesso à informação e à participação que possibilite a conscientização e a auto-gestão da população;

- Promoção da saúde pública;

- Promoção da educação sanitária e ambiental que vise à construção da consciência individual e coletiva e de uma relação mais harmônica entre o homem e o ambiente;

- Orientação pela bacia hidrográfica;

- Sustentabilidade;

- Proteção ambiental;

- Informação tecnológica.

Embora seja observada tendência à modificação das políticas públicas nacionais, e uma busca por maior envolvimento social nas tomadas de decisão no escopo sanitário, o país ainda conta com déficits nessa temática. Os serviços básicos, quando analisados sob a ótica da universalidade, apresentam caráter desigual, acompanhando os atributos de escolaridade e renda da população, "o que remete a uma segregação social” (da Silva, 2012). 


\section{4- DESENVOLVIMENTO SOCIAL E SANEAMENTO AMBIENTAL}

A noção de desenvolvimento humano via crescimento econômico é comumente aceita entre diferentes esferas da sociedade, partindo do pressuposto que renda familiar e qualidade de vida são grandezas diretamente proporcionais. Todavia, conferências como a ECO 92 e o relatório Brundtland incorporaram a noção da temática ambiental à realidade mundial espelhando a insuficiência dos postulados socioeconômicos em meio a crises ecológicas que marcavam a metade do século XX -, cerceando e freando a busca pelo crescimento econômico do sistema industrial moderno em favor de um desenvolvimento sustentável (LOBO, 2001), voltando as atenções para a qualidade de vida do Homem imerso no ambiente. Tal tendência ecossustentável na economia é vista por teóricos como essencial para a sociedade, segundo Cardoso (1993 apud LOBO, 2001 p. 11) “a idéia do progresso técnico e da racionalidade não é descartada, mas redefinida. O objetivo agora é o cálculo social dos custos e benefícios [...] O alvo é a expansão do bem estar coletivo, não um aumento da produção."

Respaldado por eclosões de movimentos sociais nas décadas de 1960 e 1970, emerge o ecodesenvolvimento liderado por Strong e Sachs; este, em sua obra "Rumo à Ecossocioeconomia: Teoria e prática do desenvolvimento" (São Paulo: Cortez Editora, 2007.) lança mão de postulados sobre o desenvolvimento ecologicamente responsável, afirmando, que há de se subestimar o poder do "remédio tecnológico"11, uma vez que se alteram os processos econômicos desde já; além disso, afirma haver cinco dimensões de sustentabilidade: social, econômica, ecológica, espacial e cultural. Sachs (ibid, p. 185) afirma que "As cidades são ecossistemas, e, enquanto tais, constituem fontes potenciais de recursos. Muitos deles são latentes, sub ou mal utilizados", além de introduzir ao ecodesenvolvimento os conceitos de descentralização política e práticas ambientais preventivas em detrimento das remediativas.

Em países em desenvolvimento, entretanto, a sustentabilidade é um caminho complexo e antagônico aos seus interesses; por não ter alcançado maturidade consumista e na qualidade de vida, esses governos veem com bons olhos práticas industriais de certo modo predatórias ao meio-ambiente, que, inegavelmente, produzem maior lucro e menor tempo de giro ao capital. Proporciona-se, assim, crescimento econômico e respostas mais rápidas à população - a qual anseia por seu ingresso em novos e superiores patamares de consumo. Sobre isso, ressalta-se que “ao ter suas necessidades básicas atendidas, o indivíduo se torna mais propenso à sensibilização ambiental"12. O alto custo de políticas sustentáveis, no entanto, é o maior embargo à passagem de

\footnotetext{
11 O remédio tecnológico é caracterizado como a capacidade da ciência em superar óbices e crises ambientais

12 Retirado em aula de LOPES, F. W. A., ministrada no Instituto de Geociências, UFMG, em setembro de 2015
} 
tais países a uma realidade "ambientalmente correta", uma vez que não há disponibilidade de tais recursos financeiros. Contudo, políticas governamentais que visem à qualidade de vida da população são responsáveis, direta ou indiretamente, pelo crescimento econômico intentado de maneira atualmente desregrada por tais nações, conforme UlHaq (1996 apud LOBO, 2001, p. 17) "estamos descobrindo o óbvio - que as pessoas são ambos o meio e o fim do desenvolvimento econômico" (tradução nossa) e Lobo (ibid., p. 26):

A expansão e o acesso aos serviços sociais básicos, independente do crescimento na riqueza ou nas rendas, pode ser fundamental à ampliação de outros tipos de liberdade, como viver mais tempo e com melhor qualidade. $\mathrm{O}$ próprio sistema educacional e os serviços de saúde também são produtivos para o aumento do processo de crescimento econômico. (grifo nosso)

Introduzido ao âmbito do saneamento nas últimas décadas, o discurso ambiental, bem como sua avaliação, tomou caráter peremptório, integrando o Homem ao ecossistema no planejamento e gestão (SOARES; BERNARDES; CORDEIRO NETTO, 2002). As áreas de risco ambiental estão majoritariamente nas cidades informais, não excluídas a problemas ambientais, de saúde e saneamento ${ }^{13}$. As moradias autoconstruídas - como sua morfologia indica - pressupõem abstenção do Poder Público em prover infraestrutura adequada, configurando essas localidades em não cidade, ou cidade fora da lei; tais áreas são resultadas de esgarçamento do tecido urbano, em regiões de baixos valores fundiários e potencial de investimento (CORREIA, 1977; MARICATO, 1997; MONTE-MÓR, 2007; ROLNIK, 2009). Tal lógica pode ser considerada como uma reprodução das condições sanitárias nos cortiços do século XIX, os quais eram a materialização do excedente populacional das cidades e contavam com índices de salubridade e qualidade de vida baixos, além de não contarem com grandes dispêndios governamentais no sentido de abordagem radical ao problema: a moradia popular. Há mais de 150 anos esse tipo de habitação é a base dos problemas sociais - não excluído o saneamento ambiental - uma vez que sua qualidade e a oferta de serviços e aparelhos urbanos são defasadas se comparadas às áreas centrais. Consoante à supra linha cognitiva, Jacobi (1995 apud ALVES, 2007) relaciona diretamente a insuficiência no acesso a serviços públicos à qualidade ambiental. A desigualdade ambiental seria, dessa maneira, originária da desigualdade social (ALVES, 2007), ou de outros tipos de dessemelhança como a racial, econômica, locacional, etc. (TORRES, 1997 apud ALVES, 2007).

A questão sanitária não deve ser vista como de caráter exclusivamente ambiental; há de se observar aspectos mais complexos que não envolvem, para sua superação, obras de engenharia ou simples aumento orçamentário dos órgãos responsáveis. Se nas metrópoles não se observa o

13 TORRES, 1997;2000 apud ALVES, 2007 
pleno atendimento às necessidades básicas da população, em zonas rurais e de menor força econômica a problemática é potencializada; o bem-estar em tais localidades não é satisfatório, havendo, de certo, tendência maior em concentração urbana em centros com maiores índices de qualidade em saneamento. Tal movimento implica em dispêndios sempre vultosos nas grandes cidades, gerando maior pressão ambiental devido ao poder atrativo delas, enquanto áreas de menor população continuam desejosas de maior conforto sanitário. Assim, é justificada a necessidade de atendimento desigual à população, de modo que os que demandam mais serviços os recebam de maneira priorizada, mitigando as desigualdades em voga (PAIM, 2011 apud HELLER, 2012).

Grandes áreas urbanizadas podem ser caracterizadas como centralidades onde há a predominância de artificialização da natureza (LIMA, 2013), nas quais o espírito humano é desconectado, parcial ou integralmente, do ambiente "natural". Epistemologias dos países colonizadores trazem o rompimento Homem-Natureza de modo a transformar esta em recursos a serem extraídos; dessa maneira, a sociedade dos territórios colonizados emula o padrão de vida e a cultura européia/norte-americana (Norte Sociológico), ratificando no âmbito local a necessidade de exploração ad nauseam do meio ambiente (SANTOS;MENESES; NUNES, 2005). É possível a inferência que o atual estágio de desenvolvimento sustentável observado em diversos casos no Norte seja lastreado em exploração/exaustão de recursos naturais em países reféns do capital estrangeiro. Nossa visão é similar à de da Silva (2012), quando este afirma serem as cidades um meio ambiente urbano, um ecossistema aberto, o qual engloba as preocupações não só de caráter natural, como as antrópicas. Segundo o autor, é necessário não apenas o desfruto dos elementos naturais, mas sua conservação, aproximando-se da intentada sustentabilidade.

Ciência de alta complexidade, o saneamento ambiental apresenta pressuposto de adequação no tocante ao modo de introduçãoem soluções em realidades locais, demandando, por conseguinte, uma abordagem interdisciplinar, dialogante e humana (HELLER; NASCIMENTO, 2005). Embora se defenda uma profunda reforma estrutural da atual conjuntura sanitária, não são desvalorizadas as obras de engenharia de escala local. O organismo patogênico e sua relação com o meio ambiente é o escopo, nessa ciência, das ações intervencionistas (SOARES; BERNARDES; CORDEIRO NETTOO, 2002); a ilação depreendida daí configura-se em incorporação dos vetores e agentes deletérios como aspectos ambientais a serem atenuados em primeira instância.

Saneamento ambiental e saúde estão fortemente imbricados, compartilhando como corolário o desenvolvimento social e, acima de tudo, humano; avançados conhecimentos técnicos 
ou cargas teóricas não são exigidos para relacionar qualidade ambiental, saneamento básico, expectativa de vida e ocorrência de doenças diarreicas. Contudo, o que se argumenta é o potencial benéfico de obras e intervenções no saneamento à população e ao governo; Briscoe (1985, apud Heller, 1998, p. 76) indica que o abastecimento de água e coleta de esgoto doméstico, entre outras ações ambientais, "podem prevenir cerca de quatro vezes mais mortes e elevar a expectativa de vida sete vezes mais, que as intervenções de natureza biomédica”. Conclui-se, daí, que o unitarismo orçamentário de saneamento e saúde pública seria benéfico, bem como coalizão de esforços nas políticas públicas, uma vez que tratam-se de medidas preventivas e remediativas de uma mesma esfera. Entretanto, há de salientar que o esgotamento sanitário apenas alcança plena eficiência quando realizado tratamento adequado de seus efluentes em redes coletoras (SOARES; BERNARDES; CORDEIRO NETTO, 2002). Caso contrário, o esgotamento pode ser entendido como instrumento incongruente às suas finalidades, uma vez que trará benefícios a uma população em detrimento de outra - afetada por poluição de cursos d'água.

A relação desenvolvimento socioeconômico e saneamento ambiental, salvo esparsas exceções, é direta e proporcional; entretanto, há de se excluir categorização tautológica determinando que a melhoria econômica implicará em superior qualidade ambiental, bem como sua recíproca. Regiões com baixo PIB per capita, por exemplo, podem contar com instrumentos sanitários adequados e eficientes às suas demandas, por meio de transferências de tecnologia e programas estatais; no entanto, as medidas domiciliares em saneamento estão fortemente amarradas à condição financeira do núcleo familiar, uma vez que em caso de elevação de renda, os primeiros esforços em investimentos são dirigidos às instalações de esgoto, captação de água e armazenamento de resíduos sólidos devido ao desejo por uma qualidade de vida recrudescida. Não se exclui, no entanto, a fundamental relevância das políticas públicas para nortear as intervenções no universo domiciliar, pois é impossível conectar tubulação de esgotamento em rede inexistente; caso contrário, o encanamento apenas resultaria em maior dano ambiental. Sobre isso, Borja (2004 apud HELLER, 2012) afirma que o "saneamento é uma meta coletiva diante de sua essencialidade à vida humana e à proteção ambiental, o que evidencia o seu caráter público e o dever do Estado na sua promoção, constituindo-se um direito social integrante de políticas públicas e sociais". O desenvolvimento intentado, no entanto, abarca uma complexa rede de atores em uma escala global; sobre o tema, Matos (2004, p. 53), afirma:

De toda a forma, ações de desenvolvimento nos dias de hoje pressupõem uma atuação estratégica dos governos na promoção das articulações entre fontes de financiamento, setores com capacidade de gerar inovações e desenhos institucionais dispostos para a negociação. O desenvolvimento sustentável não foge a essa regra, pelo contrário, a reforça. 
No escopo regional, Cunha, Simões e de Paula indicam a necessidade de se "considerar as especificidades regionais, a paisagem natural e seu estoque de recursos, a partir das idéias da cautela, da sustentabilidade, da biodiversidade” (2005, p 5).

O padrão de consumo vigente, juntamente com o incremento populacional e o uso de tecnologias podem ser considerados os principais atores de modificação ambiental; o sobreconsumo é de certa forma homologado com o discurso de "fé da ciência", o qual nos induz a crer que a P\&D sempre dará conta de superar óbices ambientais (SILVA, 2008, p. 38). No Brasil, os processos de industrialização e urbanização ocorreram com vertiginosa velocidade ${ }^{14}$, preterindo a questão ambiental e incentivando o consumo excessivo, tendo como corolário-mor dessa lógica a questão dos resíduos sólidos urbanos, responsáveis por grande pressão socioambiental no início do século XXI. No escopo domiciliar, observa-se nas últimas décadas o crescimento do número dos pequenos domicílios - nos quais os indivíduos ali permanecem por poucas horas do dia e ocorra predominância de adultos - que apresentam tendência ao consumo de produtos práticos, ágeis, gerando um maior volume de resíduos (SILVA, 2008). Não obstante, o tempo disponível dos indivíduos é o principal fator de comportamento amigável ao meio ambiente (TANGLET et al, 2004 apud SILVA, 2008), pouco observável em chefes de tais residências. A problemática dos resíduos sólidos é reforçada pelo comportamento da "cidadecensura", dispondo-os distantes das vistas da população (OGATA, 1999 apud SILVA, 2008); dessa forma, a conscientização da população torna-se mais difícil uma vez que se joga "a sujeira por debaixo do tapete", estabelecendo um ciclo vicioso de consumo excessivo e má destinação dos resíduos.

\section{5- PESQUISAS QUANTITATIVAS: CONTRIBUIÇÃO ACERCA DO SANEAMENTO}

Nesta seção serão abordados breve e sucintamente alguns trabalhos pertinentes à questão sanitária, reproduzindo-os a fim de destacar não apenas a identidade dos estudos em saneamento (precipuamente os quantitativos), como também a universalidade e qualidade dos serviços prestados em escala nacional.

Alves (2007, p. 312) indica que há mudanças no saneamento domiciliar de baixa renda, relacionadas à locação entre áreas de risco e não-risco ambiental no município de São Paulo

Em particular, a cobertura de coleta de esgoto apresenta um diferencial muito significativo entre as áreas de risco e as de não-risco, no interior das regiões

${ }^{14}$ Ibid. p. 43 
pobres, com respectivamente $61,1 \%$ e $77,9 \%$ [...]. Portanto, as condições sanitárias são significativamente piores nas áreas de risco ambiental em relação àquelas de não-risco, o que confirma a associação entre risco ambiental e más condições sanitárias, principalmente nas áreas à beira de cursos d'água.

Nestas últimas regiões, os resultados indicam cobertura da coleta de esgoto em 57,8\% dos domićlios. Tais números corroboram a hipótese da defasagem em saneamento ambiental não ser questão puramente econômica, uma vez que o município mais rico do Brasil apresenta deficiência na coleta de esgoto em domicílios pobres. Essa teoria também encontra ratificação em dados do Ministério das Cidades os quais apontam que 52\% dos déficits em serviços de saneamento residem em cidades com população superior a um milhão (BRASIL, 2007 apud da Silva, 2012) e no postulado de Gomes (2009 apud da Silva, 2012) que indica insuficiência nos serviços em saneamento em áreas de risco no município de Belo Horizonte.

Em metodologia similar à dessetrabalho, Lima (2013) analisou a qualidade ambiental do município de Presidente Epitácio/SP, identificando áreas as quais apresentam condições adequadas, parcialmente adequadas e inadequadas em saneamento. Os resultados indicam situação domiciliar de predominância espacial do modo "fossa rudimentar" em esgotamento; dessa maneira, a autora comenta que "o que não está visível influencia muito mais negativamente do que os fatores aparentemente visíveis"(ibid. p. 82), elevando a importância da análise quantitativa em saneamento, embora a diferenciação "fossa séptica/rudimentar" seja de difícil percepção em centros urbanos, alterando a precisão dos resultados (REZENDE; RIBEIRO, 2004). Roberts (1997, apud HELLER, 1998, p.83) extrai três conclusões a partir de uma coletânea de estudos desenvolvidos em âmbito metodológico-conceitual, apesar de não serem consideradas de caráter determinante para implementação de políticas públicas:

1) $\mathrm{O}$ acesso a instalações para a disposição de excretas é geralmente mais protetor contra a diarréia que o acesso a maior quantidade de água ou a água mais limpa.

2) Quantidades adequadas de água parece ser mais benéfico na redução de taxas de diarréia que o acesso a água de melhor qualidade.

3) Melhoria na qualidade da água é relativamente vulnerável a ter seus benefícios anulados por outros fatores comportamentais ou ambientais.

Caminhos que levemao benefício à sociedade na $\mathrm{P} \& \mathrm{D}$, apesar de sua premência, são raros na esfera do saneamento e demandam elementos norteadores para tal; não obstante, a maior parcela de trabalhos confeccionados aborda ações de abastecimento de água e coleta de esgoto, configurando de certo modo uma análise parcial da conjuntura do saneamento nacional. Observa-se, logo, necessidade de atualização ante a ciência internacional, bem como inovação e aplicabilidade tecnológica, além de acumulação de reflexões teóricas sobre o tema, a fim de obter 
alcance de melhoria ambiental a toda população (HELLER; NASCIMENTO, 2005). Ainda na mesma obra, os autores conferem à pesquisa a necessidade de estudo de "temas como o grau de desenvolvimento econômico do país, seus desequilíbrios sociais e ambientais e a maturidade das práticas políticas" (p. 27), bem como análises quantitativas para compreender a "realidade sanitária" (p. 27) precípua às universidades. Tais métodos, entretanto, devem ser acompanhados de revisões bibliográficas de modo a relacionar fatores não controláveis em laboratório, como a carga sócio-cultural da população e organismos gestores, além do contato direto com os impactados pelas intervenções sanitárias, através do diálogo, integração com a saúde (noção ainda pouco arraigada), avaliação do serviço, controle social e tarifas módicas ${ }^{15}$. Para isso, Heller e Nascimento (ibid., pgs. 29 e 30, 2005) indicam cinco tópicos a serem seguidos pela P\&D: "formação de recursos humanos, divulgação científica e tecnológica, transferência de tecnologia, fomento [...] e avaliação da pesquisa". Os autores sugerem a possibilidade de maior ordenamento e protocolamento acadêmico no país, culminando em uma política nacional.

Os parágrafos que se seguem detalharão dados censitários no escopo do saneamento básico brasileiro, de modo a destacar a evolução da melhoria ambiental na escala domiciliar nas últimas décadas.

De acordo com a FIBGE (1991, apud HELLER, 1998), 32\% da população brasileira não eram conectados à rede coletiva de água, 68\% não eram atendidos por sistema coletivo de esgotos e $44 \%$ da população brasileira não era atendida por serviços de coleta de resíduos sólidos nessa data.

Em 2007 uma pesquisa conduzida por Rezende et al apresenta duas tabelas que sintetizam o diagnóstico feito pelos autores sobre o saneamento básico brasileiro no ano de 2000, sendo a primeira com enfoque domiciliar (tabela 2) e a segunda municipal (tabela 3), as quais nos permitem analisar e confrontar a situação sanitária brasileira em um período anterior ao atual. Observa-se que as disparidades no recorte domiciliar estão diretamente conectadas à renda familiar, ratificadas pelo número de moradores e anos de estudo. No âmbito municipal se destacam unidades administrativas com IDH altos, de grande porte e que sejam geridos através de autarquia municipal ou da Unidade Federativa circunscrita.

${ }^{15}$ Ibid., p. 27 
Tabela 2: Brasil: cobertura de rede de abastecimento de água e de esgotamento sanitário segundo características dos domicílios urbanos e de seus responsáveis, 2000 (\%)

\begin{tabular}{|c|c|c|c|c|c|c|c|}
\hline Variáveis & Categorias & $\begin{array}{c}\text { Rede de } \\
\text { água }\end{array}$ & $\begin{array}{l}\text { Rede de } \\
\text { esgotos }\end{array}$ & Variáveis & Categorias & $\begin{array}{c}\text { Rede de } \\
\text { água }\end{array}$ & $\begin{array}{l}\text { Rede de } \\
\text { esgotos }\end{array}$ \\
\hline \multirow[t]{2}{*}{ Sexo } & masculino & 90,1 & 60,3 & \multirow[t]{12}{*}{ Grupo ctário } & $15-19$ & 80,5 & 46,1 \\
\hline & feminino & 89,4 & 56,8 & & $20-24$ & 84,8 & 50,1 \\
\hline \multirow[t]{2}{*}{ Cor } & negra/parda & 85,1 & 49,4 & & $25-29$ & 87,5 & 52,8 \\
\hline & branca/amarela & 92,7 & 63,6 & & $30-34$ & 89,0 & 54,7 \\
\hline \multirow[t]{2}{*}{ Estado civil } & solteiro & 84,8 & 50,4 & & $35-39$ & 89,8 & 56,6 \\
\hline & não soltciro & 91,3 & 60,5 & & $40-44$ & 90,5 & 58,6 \\
\hline \multirow{5}{*}{$\begin{array}{l}\text { Anos de } \\
\text { estudo }\end{array}$} & $0-1$ & 81,9 & 44,9 & & $45-49$ & 90,7 & 60,0 \\
\hline & $2-3$ & 86,1 & 50,6 & & $50-54$ & 90,6 & 60,4 \\
\hline & $4-7$ & 90,0 & 57,4 & & $55-59$ & 90,3 & 60,1 \\
\hline & $8-10$ & 93,5 & 64,1 & & $60-64$ & 90,3 & 60,5 \\
\hline & $11 \mathrm{c}$ mais & 96,1 & 77,6 & & $65-69$ & 90,2 & 61,2 \\
\hline \multirow{5}{*}{$\begin{array}{l}\text { Renda } \\
\text { domiciliar } \\
\text { (salários } \\
\text { mínimos) }\end{array}$} & $<0,5$ & 80,7 & 46,1 & & $70 \mathrm{e} \mathrm{mais}$ & 90,7 & 62,3 \\
\hline & $0,5-1,5$ & 81,6 & 43,6 & \multirow{4}{*}{$\begin{array}{l}\text { Total de } \\
\text { moradores }\end{array}$} & $0-3$ & 90,1 & 58,7 \\
\hline & $1,5-3,0$ & 87,0 & 49,6 & & $4-5$ & 89,1 & 54,5 \\
\hline & $3,0-5,0$ & 90,9 & 57,0 & & $6-8$ & 82,6 & 44,2 \\
\hline & $>5,0$ & 94,8 & 70,3 & & $9 \mathrm{c}$ mais & 77,6 & 37,8 \\
\hline
\end{tabular}

Fonte de dados básicos: IBGE/Censo Demográfico de 2000 e PNSB de 2000.

Retirado de: REZENDE, Sonaly et al. Integrando oferta e demanda de serviços de saneamento: análise hierárquica do panorama urbano brasileiro no ano 2000. Eng. Sanit. Ambient., Rio de Janeiro , v. 12, n. 1, p. 90-101, Mar. 2007.

Tabela 3: Brasil: Cobertura de rede de água e esgotos nos domicílios urbanos segundo macrorregiões, modelos de gestão, IDH municipal e porte do município, 2000 (\%)

\begin{tabular}{cccccc}
\hline Macrorregióes & $\begin{array}{c}\text { Rede de } \\
\text { água }\end{array}$ & $\begin{array}{c}\text { Rede de } \\
\text { esgotos }\end{array}$ & Modelos de gestão & $\begin{array}{c}\text { Rede de } \\
\text { água }\end{array}$ & $\begin{array}{c}\text { Rede de } \\
\text { esgotos }\end{array}$ \\
\hline Norte & 77,4 & 12,1 & Adm. Direta Municipal & 90,7 & 40,5 \\
Nordeste & 80,9 & 36,6 & Autarquia Municipal & 94,0 & 50,4 \\
Sudeste & 94,0 & 79,6 & Estadual & 90,2 & 52,2 \\
Sul & 92,3 & 33,8 & Federal & 82,7 & 17,7 \\
Centro Oeste & 80,0 & 35,1 & Particular & 83,3 & 17,9 \\
Brasil & 94,9 & 39,4 & & & \\
IDH municipal & Rede de & Rede de & Porte municipal & Rede de & Rede de \\
(habitantes) & água & esgotos \\
Baixo: $<0,500$ & 63,9 & 2,2 & $>5$ mil & 85,2 & 31,8 \\
Médio: 0,501 - 0,799 & 85,7 & 44,0 & $5-20$ mil & 85,9 & 41,2 \\
Alto: $>0,799$ & 95,1 & 74,1 & $20-50$ mil & 87,3 & 49,6 \\
& & $50-200$ mil & 89,5 & 56,4 \\
& & $>200$ mil & 92,8 & 69,5 \\
\hline
\end{tabular}

Retirado de: REZENDE, Sonaly et al. Integrando oferta e demanda de serviços de saneamento: análise hierárquica do panorama urbano brasileiro no ano 2000. Eng. Sanit. Ambient., Rio de Janeiro, v. 12, n. 1, p. 90-101, Mar. 2007

O Censo Demográfico de 2010 aponta a cobertura de 92\% dos domicílios brasileiros em rede de abastecimento de água, embora apenas 64,5\% apresentem rede de esgoto (IBGE 2010 apud HELLER, 2012); tais números demonstram manutenção do panorama sanitário brasileiro do século XX. Os dados da Pesquisa Nacional de Saneamento Básico de 2008 indicam, conforme 
análise estatística realizada por Heller (ibid., p. 89), que o país apresenta valores baixos na captação e tratamento do esgoto doméstico, enquanto os números de reclamações por falta de água e inadimplência são elevados. No tangente ao modelo de gestão, o autor apresenta em sua Tese tabela síntese dos resultados obtidos no Brasil (ibid., p.98), aqui reproduzida:

Tabela 4: Síntese do desempenho dos modelos de prestação de serviços

\begin{tabular}{|c|c|c|}
\hline Modelo & Pontos Positivos & Pontos Negativos \\
\hline $\begin{array}{l}\text { Administração } \\
\text { direta municipal }\end{array}$ & $\begin{array}{l}\text { - Valores baixos de reclamações sobre o } \\
\text { valor cobrado }\end{array}$ & $\begin{array}{l}\text { - Menores índices de hidrometração } \\
\text { - Maiores indices de inadimplência } \\
\text { - Menor extensão de interceptores de } \\
\text { esgotos por ligações } \\
\text { - Menores índices de tratamento } \\
\text { secundário de esgotos }\end{array}$ \\
\hline $\begin{array}{l}\text { Administração } \\
\text { indireta municipal }\end{array}$ & $\begin{array}{l}\text { - Maiores indices de cobertura por rede } \\
\text { de esgotos (análise não paramétrica) }\end{array}$ & $\begin{array}{l}\text { Valores elevados de reclamações para } \\
\text { os aspectos de falta e qualidade da água }\end{array}$ \\
\hline Empresas Privadas & $\begin{array}{l}\text { - Maiores índices de hidrometração } \\
\text { - Menores índices de inadimplência } \\
\text { - Maiores índices de cobertura por rede } \\
\text { de água (análise paramétrica) }\end{array}$ & $\begin{array}{l}\text { - Valores elevados de reclamações para } \\
\text { os aspectos de qualidade da água }\end{array}$ \\
\hline $\begin{array}{l}\text { Companhias } \\
\text { Regionais }\end{array}$ & $\begin{array}{l}\text { - Valores elevados de interceptores de } \\
\text { esgotos por ligações } \\
\text { - Maiores índices de tratamento } \\
\text { secundário de esgotos }\end{array}$ & $\begin{array}{l}\text { - Valores elevados de reclamações sobre } \\
\text { o valor cobrado } \\
\text { - Menores índices de cobertura por rede } \\
\text { de água (análise não paramétrica) }\end{array}$ \\
\hline
\end{tabular}

Retirado de: HELLER, P. G. B. Modelos deprestação dos serviços de abastecimento de água e esgotamento sanitário: uma avaliação comparativa do desempenho no conjunto dos municípios brasileiros. 109 p. Tese (Doutorado em Saneamento, Meio Ambiente e Recursos Hídricos) - Escola de Engenharia, Universidade Federal de Minas Gerais, Belo Horizonte. 2012.

No escopo da geração de resíduos sólidos, Silva (2008) indica que a produção diária por habitante em Belo Horizonte passou de 0,25kg em 1975 para 1,26kg em 2005, acompanhando a mudança do padrão de consumo desencadeada nesse ínterim. Observa-se que as regionais e áreas de ponderação com maior renda são responsáveis pela maior geração de resíduos per capita do município, enquanto nas localidades de menor renda, há conseqüente menor geração. Além disso, domicílios unipessoais, de casais sem filhos e de casais com quatro ou mais filhos são responsáveis pela maior produção de resíduos per capita. O nível de renda também indica o tipo de rejeito primordialmente gerado; em áreas mais pobres, observam-se os resíduos orgânicos, enquanto em áreas de elevadas rendas o principal tipo de resíduo seja oreciclável. Embora englobe apenas um município, é esperado que tal realidade seja vigente em grande parte do Brasil, uma vez que os resultados correspondem como arcabouço teórico.

\section{6- CONSIDERAÇÕES FINAIS}

O saneamento ambiental adequado, embora seja um direito de todo cidadão, ainda pode ser considerado um privilégio que grande parcela da população ainda aspira. Entretanto, se comparada a períodos anteriores, o atual momento sanitário brasileiro caminha na direção do 
alcance da Universalidade, Equidade e Integralidade dos serviços, embora ainda distante se defrontado com países em elevada maturidade ambiental. Contudo, é observada ao longo da história nacional propensão a não sanção (bem como rudimentar fiscalização) de políticas públicas radicais no âmbito do saneamento, reproduzindo problemáticas que ainda perduram.

O investimento em pesquisa e desenvolvimento apresenta-se como potencial resolução de problemas sanitários à máquina pública; nas fases teóricas e práticas, a Academia demonstra-se preparada a dar passos na direção de um adequado atendimento à população de baixa renda, seja por meio de educação ambiental, instalações sanitárias e obras de engenharia. Todavia, o investimento em inovação tecnológica é feito sobretudopelo setor privado, auxiliando a manutenção de uma lógica de segregação econômica do saneamento, devido aos altos valores praticados em soluções individuais de saneamento.

O saneamento urbano se apresenta muitas vezes como algo estritamente político, sem amarração ao meio físico e à participação popular. No entanto, os sistemas geoambientais, aos quais se inserem as cidades e as bacias hidrográficas, são determinados pela qualidade, quantidade e dinâmica das interações entre os elementos naturais. Se considerarmos a malha urbana um ecossistema, o saneamento ambiental é o responsável pela manutenção de sua vida, uma vez que é etapa basilar da saúde pública; ora, é impossível considerar auspicioso um sistema de saúde dito unificado se não engloba o saneamento.

A integralidade intentada demanda trânsito escalar em dois planos; o primeiro se configura na compactuação entre os governos municipais/metropolitanos, estaduais e Federal, buscando o compartilhamento de diretrizes e ações. O segundo se materializa nas abordagens coletiva e individual de saneamento: ao governo não basta apenas a realização de obras de engenharia, como também o trabalho de educação ambiental e fiscalização eficiente no âmbito domiciliar. Muitas vezes, entretanto, medidas originalmente individuais (como a eliminação de vetores) não são realizadas, comprometendo todo o sistema de saúde pública. Tal problemática tem como cerne a cultura do país, e dificilmente será superada por meio de educação ambiental. Deve-se lançar mão de multas e intensa fiscalização, somadas à busca contínua pela melhoria das moradias populares.

As políticas públicas devem ser adequadas à realidade nacional, e isso envolve o uso racional dos recursos financeiros na construção das habitações de interesse social. Há de se evitar o comprometimento financeiro do país, o que culminará na manutenção de disparidades e insegurança econômica não só a investidores privados, como na população de um modo geral. As intervenções governamentais têm viés esteticista, talvez para escamotear a má gestão pública, responder a investimentos externos e seguir tendências urbanísticas. Rios saturados de efluentes 
são tampados, lixões são isolados, desperdícios de recursos hídricos são acobertados e assim marcha o Brasil.

$\mathrm{Na}$ esfera dos resíduos sólidos, propõe-se a criação de parcerias público-privadas na implantação de tecnologias de manejo, além do incremento do valor pago pelos materiais recicláveis recolhidos por catadores. No que tange à utilização de recursos hídricos, a P\&D deve ser incentivada em relação a práticas de reutilização da água na indústria, bem como a racionalização desse recurso na agropecuária. Devem ser postas em andamento ações que visem à manutenção de vegetação nativa das bacias e sub-bacias hidrográficas que abasteçam os municípios. Ao esgotamento, sugere-se a criação de fundo pecuniário misto (público e privado), capaz de complementar o serviço prestado proporcionando sua universalidade, além de profundo tratamento ao esgoto doméstico em rede coletora; essas ações são de cunho coletivo e têm como escala as microrregiões dos estados brasileiros. Quanto às soluções individuais de saneamento, a pesquisa e desenvolvimento produzida nas Universidades deve servir na adequação ambiental de tal modalidade, além das transferências de tecnologia e a melhoria das habitações de interesse popular - todas proporcionadas pelo Estado.

\section{REFERÊNCIAS BIBLIOGRÁFICAS}

ALVES, H. P. F. Desigualdade ambiental no município de São Paulo: análise da exposição diferenciada de grupos sociais a situações de risco ambiental através do uso de metodologias de geoprocessamento. Rev. bras. estud. popul., São Paulo , v. 24, n. 2, p. 301-316, Dec. 2007

BENTHAM, J. An Introduction to the Principles of Morals and Legislation. Oxford: Clarendon Press. 1907. Library of Economics and Liberty [Online]. Disponível em: $<<$ http://www.econlib.org/library/Bentham/bnthPMLO.html $>>$ acesso em 19 de agosto de 2015.

BRASIL. Guia para elaboração de planos municipais de saneamento. Ministério das Cidades Brasília :MCidades, 2006. 152 p.

BRASIL. Decreto n. 7217, de 21 de junho de 2010. Regulamenta a Lei no 11.445, de 5 de janeiro de 2007, que estabelece diretrizes nacionais para o saneamento básico, e dá outras providências.

CHALHOUB, S. Cidade Febril: cortiços e epidemias na Corte imperial. São Paulo: Companhia das Letras, 1996. 272 p.

CORREIA, R. L. Região e organização espacial. São Paulo: Editora ática, 2ª Ed, 1977.

CUNHA, A. M. ; SIMÕES, R. F.; de PAULA, J. A. Regionalização e história: uma contribuição introdutória ao debate teórico-metodológico. Belo Horizonte: UFMG/Cedeplar, 2005. 24 p. 
GEIGER, P. P. Refletindo sobre a regionalização no Brasil e a hipótese da cidade/região global: Um ensaio. In: ENCONTRO NACIONAL DA ANPUR, 9., 2001, Rio de Janeiro. Anais... Rio de Janeiro: ANPUR, 2001. p.1745 - 1755.

HELLER, L. Relação entre saúde e saneamento na perspectiva do desenvolvimento. Ciênc. saúde coletiva, Rio de Janeiro , v. 3, n. 2, p. 73-84, 1998.

HELLER, L.; NASCIMENTO, N. de O. Pesquisa e desenvolvimento na área de saneamento no Brasil: necessidades e tendências. Eng. Sanit. Ambient., Rio de Janeiro , v. 10, n. 1, p. 2435, Mar. 2005.

HELLER, L.; REZENDE, S. C.; HELLER, P. G. B. Participação e controle social em saneamento básico: aspectos teóricos-conceituais. In: CEARÁ. Regulação: controle social da prestação de serviços de água e esgoto. Fortaleza: Pouchain Ramos, 2007, p. 37-68.

HELLER, L.; CASTRO, J. E. Política pública de saneamento: apontamentos teóricoconceituais. Eng. Sanit. Ambient. [online]. 2007, vol.12, n.3, p. 284-295.

HELLER, P. G. B. Modelos de prestação dos serviços de abastecimento de água e esgotamento sanitário: uma avaliação comparativa do desempenho no conjunto dos municípios brasileiros. 2012. 108 f. Tese (doutorado em Saneamento, Meio Ambiente e Recursos Hídricos). Curso de Pós-graduação em Saneamento, Meio Ambiente e Recursos Hídricos da Universidade Federal de Minas Gerais, Belo Horizonte, 2012.

LIMA, V. Saneamento Ambiental como indicador de análise da qualidade ambiental urbana. Caderno Prudentino de Geografia, Presidente Prudente, n.35, v.2, p.65-84, ago./dez.2013.

LOBO, C. F. F. Desenvolvimento e qualidade de vida: limitações na utilização de indicadores do crescimento econômico. Cadernos do Leste, Belo Horizonte: IGC/LESTE, v.1, n.3, out. 2001.

MARICATO, E. Brasil 2000: qual planejamento urbano?. Cadernos IPPUR, Rio de Janeiro, Ano XI, Nos1 e 2, p. 113-130, jan-dez. 1997.

MATOS, R. Grandes territorialidades, planejamento e questões ambientais no Brasil. Cadernos do leste/Universidade Federal de Minas Gerais. Instituto de Geociências. Departamento de Geografia. Laboratório de Estudos Territoriais. Vol. 1, n.1. Belo Horizonte: O Laboratório, 2000.

MONTE-MÓR, R. L. de Melo. Planejamento urbano no Brasil: emergência e consolidação. Etc..., espaço, tempo e crítica, [S.l.], No 1 (4), V. I, Jun. 2007.

REZENDE, S. C.; RIBEIRO, A. J. F. A utilização dos dados demográficos em saneamento uma aplicação ao estado de Minas Gerais. In: João Antonio de Paula \& et alli (ed.) Anais do XI Seminário sobre a Economia Mineira. Cedeplar - UFMG, 2004.

REZENDE, Sonaly et al. Integrando oferta e demanda de serviços de saneamento: análise hierárquica do panorama urbano brasileiro no ano 2000. Eng. Sanit. Ambient., Rio de Janeiro , v. 12, n. 1, p. 90-101, Mar. 2007. 
ROLNIK, R. Democracia no fio da navalha - limites e possibilidades para a implementação de uma agenda de reforma urbana no Brasil. Revista Brasileira de Estudos Urbanos e Regionais, [S.I.], V. 11, N. 2, Nov. 2007.

SACHS, I. Rumo à ecossocioeconomia: teoria e prática do desenvolvimento. Paulo Vieira Freire (org.). São Paulo: Cortez, 2007. 200 p.

SANTOS, B. de Sousa (org.). Semear outras soluções - os caminhos da biodiversidade e dos conhecimentos rivais. Rio de Janeiro: Civilização Brasileira, 2005.504 p.

SILVA, H. Aspectos demográficos associados à geração de resíduos domiciliares no município de Belo Horizonte, 2002. 2008. 190 f. Dissertação (Mestrado em Demografia) - Curso de pósgraduação em Demografia, Universidade Federal de Minas Gerais, Belo Horizonte, 2008.

da SILVA, P. E. A. B. Índice da qualidade do saneamento ambiental aplicado na região metropolitana de Belo Horizonte. 2012. 120 f. Dissertação (Mestrado em Análise e Modelagem de Sistemas Ambientais) - Curso de pós-graduação em Análise e Modelagem de Sistemas Ambientais, Universidade Federal de Minas Gerais, Belo Horizonte, 2012.

SOARES, S. R. A.; BERNARDES, R. S.; CORDEIRO NETTO, O. de M.. Relações entre saneamento, saúde pública e meio ambiente: elementos para formulação de um modelo de planejamento em saneamento. Cad. Saúde Pública, Rio de Janeiro , v. 18, n. 6, p. 17131724, Dec. 2002. 